\title{
"A POESIA É O PARAÍ́SO DO PARADOXO": \\ Entrevista com Rodrigo PETRONIO
}

\author{
Antônio Donizeti PIRES ${ }^{3}$ \\ Patrícia Aparecida $\mathrm{ANTONIO}^{4}$
}

Rodrigo Petronio nasceu em São Paulo, em 1975, e é formado em Letras

Clássicas pela USP. Como poeta, estreou em 2000, com História natural, logo seguido de Assinatura do sol (2005), publicado em Portugal, e pelo livro de ensaios Transversal do tempo (2002; Prêmio Jordão Emerenciano 2001, do Conselho Municipal de Cultura da Cidade do Recife), importante repositório do paideuma pessoal do autor e indicador de questões poéticas e filosóficas que lhe são caras. Em 2005, o poeta nos brinda com o fundamental Pedra de luz (finalista do Prêmio Jabuti 2006), seguido de Venho de um país selvagem (2009), vencedor do Prêmio Academia de Letras da Bahia/Braskem de 2007 e do Prêmio da Fundação Biblioteca Nacional (FBN). Na entrevista abaixo o poeta dá a conhecer-se um pouco mais, revelando-nos o seu processo criativo, as suas ideias sobre poesia, filosofia e religião, e as suas opiniões sobre os quadros da poesia brasileira contemporânea.

1. Num dos poemas de Venho de um país selvagem, você afirma "Quero ser estrangulado pelo canto que me liberta / Profundamente estrangulado pelo seu punho necessário". Qual o lugar da inspiração e do artesanato no seu processo criativo? Onde começa e termina o poema?

3 Departamento de Literatura. Programa de Pós-Graduação em Estudos Literários. Faculdade de Ciências e Letras, Universidade Estadual Paulista (UNESP), campus de Araraquara, CEP 14800-901, Araraquara - SP Brasil-adpires@,fclar.unesp.br

4 Doutoranda (bolsista CAPES). Programa de Pós-Graduação em Estudos Literários. Faculdade de Ciências e Letras, Universidade Estadual Paulista (UNESP), campus de Araraquara, CEP 14800-901, Araraquara - SP Brasil-gafinha@yahoo.com.br 
A pergunta de vocês nos remete ao cerne, não só da criação poética, mas de todo ato criativo. Ela me interessa tanto do ponto de vista da criação quanto de um ponto de vista teórico. Do ponto de vista teórico, desde as reflexões platônicas e aristotélicas, o debate sobre a criação oscila de modo pendular entre o furor e a techné, ou seja, entre aquilo que mais tarde os latinos chamarão de ingenium e studium. Porém, acredito que em boa medida essa dicotomia tenha sido produzida por uma leitura posterior, de cunho idealista, que ignora o papel central desempenhado pela ascese intelectiva e pela intuição das essências presente na teoria das formas de Platão. Afinal, embora Sócrates não seja poeta, é um endemoninhado: cheio de daimon. Ou seja: a intuição das essências formais efetuada pela filosofia, tal como a poesia, também é fruto de um ímpeto divino. A teoria das formas, tanto inteligíveis quanto sensíveis, ou seja, tanto por via filosófica quanto poética, estaria fundada em duas premissas de possessão: uma pelo daimon e outra pela inspiração divina. E a verdade platônica não são conteúdos mentais, mas realidades formais preexistentes, concretas e objetivas, que se revelam à consciência por meio da anamnese. Do mesmo modo, há uma tradição peripatética muito importante, vinculada ao Problema XXX, portanto, rigorosamente aristotélica, que trata do papel central da melancolia e da bílis negra na criação poética. Ou seja: há uma psicofísica da criação pressuposta na teoria aristotélica. Conectada à teoria dos humores e contra a crença comum de que Aristóteles teria valorizado apenas o studium a despeito do entusiasmo, essa psicofísica poética serve de base a uma teoria da possessão e da loucura divina que chega até a Renascença. O que isso demonstra? Um fato muito interessante: a teoria platônica, que deu origem a toda a metafísica poética da inspiração no Ocidente, é, na verdade, uma teoria de formas, não de conteúdos prévios a serem veiculados, e a teoria da imanência poética de cunho aristotélico, que seria a versão mais antiga da concepção do poeta como artesão e da poesia como artesanato, se fundamenta em premissas psicofísicas, ou seja, em pressupostos anímicos. A partir dessa leitura, podemos efetuar uma inversão nas leituras correntes das tradições clássicas e instaurar um paradoxo: a teoria platônica do entusiasmo, ao contrário de veicular um hipotético conteúdo subjetivo ou psicológico, visaria acessar as Formas, ao passo que a defesa aristotélica da techné, à medida que se relaciona ao temperamento melancólico e aos humores, teria uma dimensão anímica. Tendo em vista esses aspectos, o velho ditado sobre a inspiração e a transpiração, ou seja, a dicotomia moderna entre forma e conteúdo, 
presente nos conceitos de inspiração e artesanato, seria uma falsa questão. Ela nasce de uma concepção equivocada do conceito de forma no debate artístico. Essa concepção parece se basear na crença de que a forma é algo restrito aos efeitos da linguagem. $\mathrm{Na}$ acepção em que a estou tomando, a forma é o próprio enquadramento que cada artista faz do mundo. A forma é o recorte do real produzido pelo olhar. A forma da Divina comédia não é apenas a terza rima e os efeitos sublimes de linguagem específicos obtidos por Dante. O teor visionário de tudo o que é narrado e pintado compõe a sua forma mentis, a sua forma mental, que é a sua estrutura imaginária, que eu chamo de estrutura arcana, para designar aquela dimensão de acesso às Formas, mencionada na teoria platônica. Por seu lado, a estrutura arcana de uma obra não é uma deliberação racional e mensurável de quem a cria, mas o conjunto de realidades eidéticas inscritas em nós, que nos possuem e nos habitam. E em linhas gerais, acredito que seja praticamente impossível acessarmos essas realidades por meio de expedientes técnicos, teóricos ou artesanais. Quanto aos meus modos de escrita e criação, lembro o que diz Lawrence: somos uma floresta sombria. Nela muitos vultos vão e vêm. O poeta é aquele que não tem álibis. E por isso contempla esses vultos e os deixa ir e vir em paz. O poeta não é aquele que atingiu o grau zero da linguagem, como sonhou o grande Mallarmé. O poeta é aquele que chegou ao grau zero de imunidade contra o mundo. E por isso, ele é um ser poroso, afetado por tudo e por todos, de todos os lados e de todas as maneiras, como soube o maior poeta da língua portuguesa, Fernando Pessoa. Não por outro motivo a poesia é irmã gêmea da loucura. E por isso mesmo, ela é por excelência um palco de agonia, no sentido tanto de tensão irresoluta quanto de luta contínua: agon. Ela é o espaço em que se desdobra um combate infinito, que não é meramente formal, mas vital. Valéry define a poesia como o paraíso da linguagem. Maravilhosa definição, mas muito categórica e luminosa. Para mim, a poesia é o paraíso do paradoxo. E o é justamente porque ela não cobra uma resolução para os opostos e para a raiz de luz e sombra, de sentido e absurdo, de esplendor e miséria que caracteriza e define a experiência humana. O poema e o poeta nada mais são do que aqueles veículos que trazem à luz o fundo de agonia, irresolução, hesitação e trauma de que somos feitos. Todo poema que escrevo nasce de algo que irrompe em minha consciência e desarticula a minha relação usual com a linguagem. Quando isso ocorre, a linguagem passa a ser a protagonista do pensamento, e não mais um instrumento daquele pequeno ego despótico que pensa dirigir a 
si próprio e aos outros. Toda experiência da beleza, sejam quais forem os âmbitos de nossa vida, vem sempre marcada por uma tensão entre algo maior do que nós mesmos que nos arrebata e a tentativa humana de tentar nomear esse arrebatamento. Para mim a poesia sempre nasce nesse fio de navalha. Por mais que eu me interesse em dominar técnicas poéticas apreendidas e aprendidas em outros poetas, e nesse sentido Pedra de luz é um livro bastante diversificado em termos de formas, ritmos e metros, e por mais que a própria poesia alheia seja inúmeras vezes minha fonte de inspiração, para mim o poema sempre nasce de uma tensão entre os limites genéricos da linguagem e a ausência de limites de uma experiência irredutível, porque absolutamente singular. Em um ensaio brilhante sobre Hölderlin, Blanchot nos dá uma bela definição: o poema é anterior ao poeta. Creio que o sentido dessa afirmação seja: o poema preexiste ao poeta porque o poema é infinito. E o é justamente porque o poema não é apenas um artesanato em uma página em branco, tampouco o veículo de um contexto social ou de uma hipotética profundidade subjetiva, mas o próprio Real que emerge no processo poético. Remetendo a Borges, o escritor é apenas um nó acidental no tecido infinito e anônimo da literatura. Esta não tem começo nem fim. Uma visão de poesia e do poema semelhante é desenvolvida por Herberto Helder em um poema não por acaso intitulado "O Poema”, no qual poema, poesia e mundo são uma coisa só. Obviamente, Helder nos engana. Trata-se de uma falsa metalinguagem, pois tudo o que se diz sobre o poema se refere, na verdade, ao mundo. O mundo é a forma pela qual o poeta habita a linguagem.

2. Murilo Mendes, na sua Microdefinição do Autor afirma: "[...] dentro de mim discutem um mineiro, um grego, um hebreu, um indiano, um cristão péssimo, relaxado, um socialista amador." Que eus discutem (ou convivem) no autor Rodrigo Petronio?

E Murilo colocou também todos os seus eus no belo Mapa, um dos grandes poemas da língua portuguesa. Fundamentalmente, em mim discutem um animal e um anjo, como diriam Pascal e Rilke. Um hominídeo e um platônico. Um pernambucano, um mineiro, um judeu, um berbere, um xamã, um cientista, um primata e um filósofo. Um perfeccionista, um conservador, um místico, um sufi, um darwinista e um louco. Um messiânico, um cristão agônico, um incendiário, um taoísta, um monge, um pagão e um profeta. 
3. E como convivem, e em que contribuem, para o processo criativo, o editor, o pesquisador, o professor e o ensaísta?

Quase com a mesma harmonia dos eus descritos acima (risos). Como quaisquer outras, essas funções correlatas ao ato de escrever oferecem vantagens e empecilhos. Para mim, oferecem mais vantagens do que qualquer outra ocupação a que eu pudesse me dedicar. Desde a adolescência tenho interesse por ensaio, teoria, filosofia e ficção. Muitos dos autores que me interessavam já eram ligados a diversas dessas áreas. Às vezes há conflitos, mas creio que consegui equacionar essas diversas frentes em um projeto comum. Acima de tudo, eu me interesso pela linguagem e pelas palavras. E pelos modos de elas tocarem o pensamento e o afeto. Pela intensidade que corre nelas. Borges diz algo muito bonito nesse sentido: de que sua vida foi inteira marcada pela linguagem. E pelo fato de saber que as palavras existem. Esse simples espanto de ver que as palavras existem e que nós as somos: isso me interessa. Mais ainda do que as suas manifestações mais formalizadas, que são a literatura e os saberes. Nesse sentido, a questão do gênero é secundária. Encontro maior intensidade em um ensaio pedregoso de filosofia ou em um texto científico ou historiográfico do que em algumas linhas de poesia e ficção que não me interessam. Então, convivo relativamente bem com essas vertentes. Além disso, tanto como professor quanto como editor venho desempenhando trabalhos cada vez mais autorais, cuja realização não só me dá prazer como considero importantes do ponto de vista político e cultural. Eles me alimentam. É o caso da edição e organização de algumas obras e autores, especialmente das obras completas de Vicente Ferreira da Silva, e das Oficinas de Escrita Criativa, que tenho desenvolvido de modo cada vez mais aprofundado. Além de criar uma espécie de método nessa área ainda incipiente, o que por si só me estimula, tenho acompanhado de perto muitos bons textos e novas vozes. Isso me deixa bastante contente e me realiza.

4. Como sua poesia dialoga com autores de inclinação mítico-mística? Que outros autores ou temas julga decisivos para a construção da sua lírica?

De fato, vocês perceberam muito bem a presença dessas matrizes em tudo o que escrevo. Tenho um grande interesse por autores inspirados em uma tradição literária que podemos definir como mítica. E também gosto muito, tanto da mística propriamente dita quanto das obras que, mesmo não sendo nomeadamente místicas, dialogam com uma dimensão da 
experiência que pode ser assim definida. A dificuldade da resposta reside na abrangência das possíveis definições de mítico e místico. Para Bataille, por exemplo, os artistas são os místicos de um mundo sem Deus. Toda a modernidade da literatura, nesse caso, reside em uma transferência das questões transcendentais das religiões a uma ordem não institucionalizada de manifestações. Para ele, uma questão teológica central, como o problema do mal, por exemplo, é melhor enfrentada por indivíduos como Brontë, Proust e Kafka do que pelos teólogos. Temos aqui uma definição bastante ampla, na qual até mesmo (e sobretudo) um autor como Sade pode entrar como representante de uma espécie paradoxal de mística ateia negativa. Por outro lado, é preciso especificar o que venha a ser mito. Quando falo em mito e pensamento mítico, já notei haver certa confusão e incompreensão do que quero dizer. Para mim o mito não é uma narrativa. O mito é a condição prévia a todas as narrativas. É uma abertura projetiva e omnicompreensiva, uma fonte de inteligibilidade do mundo. Ele não admite nenhuma cisão positiva entre uma esfera real e uma esfera de representação, pois é a condição prévia de sustentação representacional dos mundos reais possíveis. O mito seria, nesses termos, uma espécie de instância última da cadeia representacional, fora da qual não haveria representação possível. Parafraseando Wittgenstein, se o mundo é tudo o que é o caso, o mito é tudo o que é mundo. Mas nesse sentido esbarramos aqui também no problema da definição. Pois partindo dessa premissa, não só a literatura e a poesia, mas as próprias línguas por si e em si mesmas poderiam ser consideradas estruturas míticas, pois elas não representam a realidade, mas criam realidade, como sugeriu Vilém Flusser. Essas concepções de mito e de mística são muito abrangentes, e creio que a maior parte dos autores e das obras nucleares para a minha escrita advenha desse horizonte de interrogações. Mesmo os autores mais prosaicos ou até satíricos me interessam justamente porque conseguem se instalar nessa abertura mítica. Ou seja: porque conseguem depreender de tipos e circunstâncias concretas uma estrutura mais geral e, por conseguinte, universal.

\section{Fale um pouco, por favor, sobre sua relação com a poesia e a figura de Dora Ferreira} da Silva.

Dora foi uma das pessoas mais luminosas que conheci. A casa da Rua José Clemente foi um dos corações intelectuais do Brasil. Corrijo: a palavra intelectual acaba de me incomodar. 
Aquela casa era a casa do ser. Uma clareira aberta. Uma realização plena do que possa vir a ser a experiência do desvelamento. Havia algo de muito especial naquele lugar. Nunca consegue identificar o quê. Continuo tentando. Mas ainda não consigo. Convivemos todas as semanas durante os últimos três ou quatro anos de sua vida. Coordenávamos juntos o centro de estudos que ela fundou, o Cavalo Azul. Os encontros eram justamente na biblioteca, antigo escritório de trabalho de Vicente Ferreira da Silva. Estávamos sempre a um passo de cruzar o umbral. É essa a impressão mais forte que guardo dos encontros com Dora e da casa e que tentei fixar em um depoimento: entrar em sua casa e em sua poesia era cruzar um umbral. Tudo às costas se dissolvia, como na descida de Orfeu. É difícil falar dela. São muitas coisas. Desde conversas que tínhamos sobre poesia e arte até sinuosos devaneios sobre a vida após a morte, a imortalidade, a alma e visões e presságios em sonho. A sua poesia era ela e apontava na direção de tudo o que ela conseguiu mobilizar ao seu redor. No modo de falar, nos grandes olhos redondos, na palma da mão sempre elevada como uma sacerdotisa. A poesia de Dora, a obra de Vicente e aquela casa persistem em mim como um sonho continuado. E vez por outra me apalpo pra saber de fato de que lado estou desse limiar.

\section{O que você acha de certas formas híbridas de expressão, como poesia/pintura, poesia/cinema?}

Cheguei a publicar um pequeno livro de poemas em Portugal, Assinatura do sol, feito em diálogo com as imagens que o fotógrafo português Joaquim Cabral fez na África, na década de 1960. Foi uma experiência difícil e bastante boa, embora nesse caso se tenham preservado ambos os discursos, o verbal e o fotográfico. Tenho interesse em criar formas dialogadas entre pintura e poesia com alguns artistas que conheço e admiro. Neste momento tenho desenvolvido mais intensamente uma atividade que sempre gostei: fotografar. Tenho pensado de modo embrionário na possibilidade de uma exposição feita de poemas e fotos. Adoraria conceber um diálogo entre poesia e música erudita. Entendo que um poema visual ou cinético não parte dos mesmos pressupostos teóricos de um poema registrado em um livro, pois o próprio livro é também ele uma forma histórica do humanismo, que ganhou ainda mais destaque na sociedade burguesa. Ou seja: é fruto de duas eras, humanista e burguesa, que estão prestes a desaparecer. Porém, nada me demove 
da crença em uma evidência material bastante forte: da Mesopotâmia até hoje, a história da linguagem verbal tem no mínimo cinco mil anos. E a própria linguagem verbal passou por dinâmicas enormes, ora de emancipação, ora de instrumentalização. Da mesma maneira, as línguas vivem em sístoles e diástoles, em contrações e expansões de possibilidades lexicais, sintáticas, semânticas, gramaticais. Nem uma vida inteira seria capaz de dar conta de todo o repertório da língua portuguesa, por exemplo. Imaginem o que seria preciso para abranger a complexidade de todas as línguas e das produções intelectuais de cada uma. Por isso, fica uma dúvida: se a especificidade do trabalho verbal já é tão vasta, abrangente e colossal, qual a real motivação de se fundir a linguagem verbal a outras linguagens? Não vejo nenhum inconveniente em nenhum tipo de experiência de linguagem. Pelo contrário, sou a favor do máximo de liberdade possível no âmbito privado. E vivemos em um mundo no qual a arte ainda pertence a uma esfera privada. Mas sempre pressinto algo de evasivo e de muito frágil na exaltação dos media como fontes inesgotáveis de possibilidades. Como diz Peter Greenaway, ele mesmo um insuspeito mestre da tecnologia, em uma afirmação muito mais correta do que pedante, a maioria esmagadora do cinema não é nada mais do que uma literatura do século XIX transposta para uma tecnologia do século XX. Ou seja: não há especificidade da linguagem da literatura e não há especificidade da linguagem cinematográfica. O resultado é uma diluição recíproca de uma linguagem em outra. Essa diluição deu grandes resultados, mas não podemos dizer que tenha de fato acrescentado algo efetivo aos potenciais específicos de cada uma dessas linguagens. Minha suspeita é a de que, a despeito de todo alarde, boa parte da arte experimental seja no fundo uma diluição recíproca de uma linguagem em outra. Pelo contrário, acredito que o maior desafio da arte esteja em um aprofundamento cada vez maior da especificidade de cada linguagem. Se vocês olharem toda a grande modernidade, eles não fizeram nada mais do que isso: criaram obras que não podem ser traduzidas em nenhuma outra linguagem. Desde o Fausto de Goethe, que é uma obra teatral que mal pode ser encenada, até Joyce, Proust, Kafka. Esses autores continuam sendo verdadeiros megalitos de resistência contra outras linguagens. Tanto que o cinema produzido a partir de suas obras é uma aproximação didática que não traduz o que venha a ser a obra. Como diz o filósofo Peter Sloterdijk, ser moderno não é nada mais do que endossar a vitória esmagadora da liberdade sobre a necessidade. $\mathrm{O}$ único problema é quando começamos a acreditar que essa vitória eliminou ou eliminará o 
conjunto de contradições que nos definem, dos antropídeos até hoje. Quando a liberdade passa a ser um valor e deixa de ser também ela um problema, estamos diante de um processo de uniformização da experiência. Desconfio de todo discurso teleológico, que louva a inovação e a tecnologia como modos per se produtores de valor. Como poderiam dizer Nietzsche e Heidegger, todo valor é uma reificação do ser. A exaltação de valores, ainda que sejam valores modernos, como a tecnologia, é uma atitude, por si mesma, prémoderna. Quem o faz parece não ter atravessado o niilismo. E quem não atravessou o niilismo não entendeu a essência ambivalente da modernidade. Não compreende nada do que está acontecendo hoje.

\section{Qual a sua posição frente à recente tradição brasileira, leia-se, mais diretamente, Con-} cretismo e João Cabral de Melo Neto?

A questão é muito pertinente, mas gostaria de pontuar algumas distinções. Primeiro ponto: a herança concretista é apenas uma das heranças e tradições da poesia brasileira. Há outras tradições, do espiritualismo (Cecília Meireles, Tasso da Silveira e Vinicius de Moraes) ao modernismo (Manuel Bandeira e Carlos Drummond de Andrade), do orfismo (Mário Faustino, Hilda Hilst, Nauro Machado e Dora Ferreira da Silva) à geração da imagem (Walmir Ayala) e à poesia alquímica (Foed Castro Chamma), da poesia épica (Gerardo Mello Mourão) e da epifania religiosa (Adélia Prado) à poesia de crítica cultural (Affonso Romano de Sant'anna e H. Dobal), da lírica meditativa (Dante Milano e Bruno Tolentino) e da poesia fescenina e pornográfica (Glauco Mattoso) ao formalismo político-existencial (Ferreira Gullar) e à vertente da transgressão (Roberto Piva e Claudio Willer), do construtivismo (Joaquim Cardozo e João Cabral) e da poesia objetivista (B. Lopes) ao primitivismo (Oswald de Andrade) e a uma poesia elementar (Manoel de Barros), da herança maldita (Maranhão Sobrinho) à práxis (Mário Chamie), do expressionismo (Augusto dos Anjos) ao impressionismo (Raul de Leoni). Entre outras tradições. Um dos problemas da herança concretista não diz respeito a suas premissas, algumas delas muito interessantes e bastante válidas. Mas à tentativa de anular a multiplicidade de tradições e a diversidade do cânone da literatura brasileira e mesmo mundial em benefício do cânone da assim chamada poesia de invenção. Segundo ponto: o concretismo em si mesmo não é homogêneo e uníssono, como muitas vezes se crê. O próprio Haroldo de Campos, em um 
ensaio importante, aponta para a dimensão pós-utópica aberta pelo eclipse dos projetos das vanguardas históricas e pelas novas configurações culturais surgidas sobretudo a partir dos anos 1970. Embora esse aspecto possa ser entendido como uma abertura à pluralidade de linguagens e de formas, e Haroldo de Campos as tenha exercitado em seus livros posteriores, acredito que a tônica de seu discurso tenha mudado pouco em relação aos pressupostos e à defesa mais dura do primado da invenção sobre os demais valores da arte. Por seu turno, outros seguidores, simpatizantes e fundadores do concretismo seguiram rumos distintos, mas sempre mais ou menos atrelados à ideologia do novo que, no fundo, tem uma base mais vanguardista do que moderna. Terceiro ponto: embora haja de fato uma vinculação histórica entre João Cabral e o concretismo, sobretudo entre ele e Augusto de Campos, a leitura formalista de sua poesia admite matizes. Parece-me que a sua poesia está mais próxima de uma concepção construtivista do que de uma matriz formalista. E mesmo o seu teor surrealista não pode ser escamoteado sem perda da essência de sua proposta.

Haja vista seu diálogo profundo com a obra de Miró. É preciso lembrar também da vinculação de Cabral à "Filosofia da composição" de Poe, ao romancero e à poesia medieval ibéricos, sobretudo a Gonzalo de Berceo. De seu diálogo com Valéry, Mondrian, Le Corbusier, Jorge Guillén e com a própria tradição popular nordestina, por mais que ele mesmo, por razões pessoais, a tenha posteriormente renegado. Ignorar essas fontes e lê-lo em uma chave formalista é continuar vinculando a sua obra de modo redutor a uma leitura exclusivamente concretista. Em resumo, como deixei claro em outros textos e entrevistas: acredito que o concretismo tenha tido uma grande importância na poesia brasileira, sobretudo no que diz respeito ao seu projeto de tradução e de atualização de poetas e poéticas. A sua herança, porém, é dúbia. Vem sempre marcada por discursos exclusivistas, que desmentem e contradizem a própria abertura teórica e criativa proposta pelos modernismos em âmbito mundial. Sobre a proposta teórica do concretismo, ao invés de dissertar sobre ela, remeto os interessados a um ensaio agudíssimo do sempre magistral Vilém Flusser, no qual ele propõe que a poesia concreta é, na verdade, abstrata.

8. Existe, de fato, crise na poesia brasileira contemporânea? Como se constrói o novo em se tratando de poesia hoje? 
Não saberia dizer se há crise. O que acredito francamente é que para se criar o novo hoje em dia, mais do que insistir em determinados credos artísticos, é preciso criar um novo horizonte teórico. Para isso, é necessário fazer uma revisão drástica de todo discurso sobre o novo produzido ao longo do século XX. E, ao invés de postular mais um novo conceito de inovação, ou seja, mais um truísmo, é preciso repensar o conceito de tradição, no sentido mais radical do termo.

\section{Na sua opinião, qual o lugar do poeta e da poesia na contemporaneidade?}

A região do poeta é uma zona de sombra. É e sempre será. O lugar do interdito. O espaço onde a palavra silencia e a linguagem fala. Outro dia, conversando com um amigo, ele me relatou um caso curioso. Em uma de suas aulas, em uma das mais importantes faculdades de comunicação de São Paulo, surgiu a questão: o que afinal hoje em dia não pode ser transformado em mercadoria? Depois de uns instantes de hesitação um aluno respondeu: a poesia. Creio que essa matéria resistente que silenciosamente colide todos os dias com o mundo dos instrumentos (Adorno) e da falação (Heidegger) seja uma das essências da poesia. Nesse sentido, a poesia será atual à medida que for transistórica e será contemporânea na medida mesma em que recusar os valores de seu tempo.

\section{Em Venho de um país selvagem podemos observar claramente o tom de conflito entre o} positivo e o negativo, a terra e o exílio, a vida e a morte. Qual a razão e a solução (ou caminho, se é que existe) para tal base conflituosa?

Excelente pergunta. E ela remete justamente à base conflituosa que mencionei acima, e que considero um dos fundamentos de toda criação. Vocês notaram muito bem esse movimento pendular em Venho de um país selvagem. Essa oscilação não é apenas poética, mas dizia respeito a uma visão de mundo conflituosa que sustentei durante muito tempo. Como vocês sugerem, de fato tenho elaborado uma espécie de saída provisória dessa aporia e dessa luta dos opostos. Para mim não se trata de uma hipotética superação das contradições, porque o ser humano não é um animal racional, mas um animal paradoxal. É a criatura por excelência que articula em si doses idênticas de fatalidade e liberdade, de esplendor e desespero, de dúvida e exaltação, ou seja, de recurso e pobreza, como disse o sempre oportuno Platão. Onde quer que se tenha eliminado as contradições do ser humano podem 
acreditar que ele se transformou em uma máquina ou em um vegetal. Porém, o modo de lidar com essa nossa condição trágica vem mudando dentro de mim. Tenho buscado algumas vias de acesso, não à eliminação da dúvida e do desespero, mas a uma possível contemplação da face luminosa do abismo. Tenho escrito pouco, sinto que algo está mudando em mim e na minha escrita. Estou deixando essa mudança ocorrer em silêncio. Tenho me interessado muito pelo taoísmo e por alquimia. A imagem de um centro tem surgido com frequência em minha mente. Sei que ele é e sempre será inatingível. Mas sei que se eu escrever em sua direção haverá uma síntese parcial entre a sombra e a luz. É isso o que tenho buscado, na poesia e na vida.

11. A obra Pedra de luz é constituída de muitos poemas longos, de versos longos (verdadeiros versículos bíblicos) e outros que obedecem à forma fixa tradicional (o soneto, por exemplo). Qual sua relação com o verso longo, com o poema longo e com a poética tradicional, já que é formado em Letras Clássicas?

Sempre gostei de poesia e de preceptivas poéticas antigas. Sobretudo das ideias de arte que podemos definir como pré-românticas. São outros critérios. Outros valores. A minha formação foi decisiva em muitos aspectos. Ela potencializou o escritor obsessivo e o leitor patológico que há em mim. Mas não creio que seria diferente se ela fosse outra. Acho que eu continuaria sendo o mesmo escritor e leitor que sou e nutrindo os mesmos interesses. O verso livre e o verso bíblico põem em relevo aquela máxima de Pound: a poesia moderna é feita essencialmente com base no ritmo, não no metro. Por isso que é sempre válida a ironia de Eliot: nenhum verso bom é livre. Mesmo quando temos versos polimétricos, que à primeira vista parecem ser livres, há um predomínio do valor rítmico, pois o ritmo é que estabelece a cesura, ou seja, demarca aquela famosa oscilação entre som e sentido que é o coração da poesia, segundo Valéry. Em Pedra de luz optei propositalmente por explorar uma gama de formas e possibilidades formais, como vocês bem notaram. A estrutura é de diversas peças poéticas encadeadas que se unificam e se diversificam ao longo do livro, como peças musicais independentes e alternantes. Em Venho de um país selvagem, a estrutura se adensou, tornando-se mais uniforme, de modo que cada poema, cujo título em geral é o primeiro verso, funciona como uma variação de um tema maior que seria a totalidade do livro. Porém, nele praticamente só há poemas em versos livres. Tenho grande 
prazer em exercitar formas fixas e também versos bíblicos e livres. Acredito que as formas fixas não sejam modos superados de escrita, pois toda forma é a exteriorização de um conceito e de uma zona da percepção que pode muito bem se cristalizar e perdurar por um tempo muito maior do que a época de sua criação. Quando pensamos que estruturas poéticas fixas estariam ultrapassadas, esquecemos que a rima foi criada nos primórdios da era cristã, como técnica de memorização dos hinos latinos nos mosteiros. Até então ela não existia. E a rima perdura até hoje, em poemas rigorosamente modernos, como um recurso importantíssimo e como um elemento técnico eficaz, mesmo nos versos livres ou polimétricos, como é o caso Canção de amor de Alfred Prufrock [de T. S. Eliot], por exemplo. Esquecemos também que formas orientais como o tanka e o haikai, entre outras, que deslumbraram tantos poetas ocidentais simbolistas e modernos, de Pessanha e Pound a Tablada e Paz, são estruturas fixas rigorosíssimas. Nesse sentido, em arte, nenhuma forma é atemporal. Mas toda forma é transistórica. De um ponto de vista estritamente pessoal, tenho exercitado mais o verso livre, pois sinto que ele se sintoniza mais com uma espécie de ritmo interno e com uma oscilação entre pensamento e forma que tem determinado a maior parte dos poemas que escrevo. É como se o verso livre fosse mais maleável a essa música e a certa tonalidade psíquica e afetiva que tenho pretendido explorar.

12. Afirmei, num breve estudo ainda no prelo $^{5}$, que as imagens, na sua poesia (principalmente em Pedra de luz), são até violentamente jorradas por uma espécie de "ejaculação barroco-surrealista". Você acha que eu exagerei? Qual a sua relação com as duas estéticas mencionadas?

Desde que não seja uma ejaculação precoce, você está coberto de razão (gargalhadas). Na universidade estudei a poesia de Luis de Góngora. Gosto da arte e da literatura da Renascença e do século XVII e li muitos autores dessa época. Também gosto da literatura hispano-americana. E há grandes escritores que navegam por uma literatura do excesso que pode ser vinculada à matriz ibérica barroca, como Lezama Lima e o próprio Octavio Paz. Dentre os projetos de vanguarda, o surrealismo é um dos que me parecem mais simpáticos.

5 Nota do Editor: O estudo do Entrevistador/Editor intitula-se "O pêndulo de Orfeu (A poesia elementar de Rodrigo Petronio)", foi comunicado na segunda edição do evento "Travessias Poéticas Brasil Portugal" (São Paulo, PUC/SP, abril de 2010), e está publicado como capítulo de livro em: BASTAZIN, Vera. (Org.). Travessias poéticas: poesia contemporânea. São Paulo: EDUC, 2011, p.71-108. 
Porém, queria apenas pontuar um aspecto relevante. Embora alguns poemas meus, sobretudo de Pedra de luz, como vocês bem apontaram, tenham uma composição de imagens que lembre muito o surrealismo e a estética dita neobarroca, gostaria de enfatizar uma diferença entre técnica e estética. Ginsberg e Claudel usam verso bíblico, e não são surrealistas nem barrocos. Boa parte do gosto do verso longo, seja ele livre ou bíblico, eu herdei de alguns dos meus poetas favoritos: Blake, Lorca, Pound, Whitman, Helder e Eliot. Helder flertou com o surrealismo e logo se afastou. Quanto a Lorca, embora se queira vincular forçosamente, a contragosto do autor, o Poeta em Nova York a esta última vertente, sabemos que há problemas nessa vinculação. No mais, nenhum deles é barroco ou surrealista. Se pensarmos em Venho de um país selvagem, por exemplo, a sua matriz é muito mais uma linha da poesia portuguesa contemporânea e os poetas vinculados ao expressionismo alemão do que o surrealismo ou o barroco. Digo isso pelo seguinte: mesmo apreciando autores de poéticas que dialogam com o surrealismo e com o barroco, não me vinculo nem quero em hipótese alguma me vincular a uma vertente surrealista ou neobarroca. Para mim o surrealismo e o barroco hispano-americano são, respectivamente, uma vanguarda histórica e um movimento de ideias que tiveram bons e maus autores e bons e maus desdobramentos. E eu não tenho o menor interesse em defendê-los ou excomungálos. Interesso-me exclusivamente por obras e autores singulares, bem como pela relação que cada autor e cada obra estabelecem com o passado. Seja este passado composto pelos Vedas, pelo Kalevala, pelo Tao te King, pelo Gilgamesh, pela Bíblia ou por Homero, Shakespeare, Dante, Cervantes, Rabelais, Keats, Rilke, Dylan Thomas ou Celan. Não tenho nenhum interesse por nenhuma plataforma estética e por nenhum movimento organizado. Interesso-me por tradições, no sentido proposto por Eliot: afinidades eletivas e pluralidades de leituras diretamente implicadas de autores e obras de tempos e espaços distintos. E, sobretudo, por tradições estabelecidas por fundamentos metafísico-formais, como, por exemplo, o caso da poesia órfica, que das inscrições órficas a Virgílio, de Virgílio a Dante e de Dante a Rilke constitui uma das maiores e mais profundas tradições da poesia jamais produzida.

13. Na verdade, juntar barroco e surrealismo é aproximar seu work in progress a poetas brasileiros como Jorge de Lima, Murilo Mendes, Foed Castro Chamma e alguns ou- 
tros da chamada Geração 1960 (como Roberto Piva e Claudio Willer). Você concorda com a afirmação? Tais poetas, mais analógicos (penso nos termos de Octavio Paz), talvez perfaçam uma linha mais subterrânea da lírica brasileira moderna, mas que permeia todo o nosso século XX. O que você pensa da afirmação?

Sim. Entendo o sentido da pergunta e concordo que haja mesmo uma tradição brasileira mais eclipsada, principalmente a de gênios como Jorge de Lima, Foed Castro Chamma e Murilo Mendes. Mas, como disse acima, prefiro sempre pensar em poetas, obras e poéticas mais do que pensar em movimentos. Nesse sentido, dentre as diversas tradições da poesia brasileira que enumerei acima, há não só uma, mas algumas que são minoritárias e precisariam ser mais bem conhecidas. A concepção de pensamento analógico de Paz, tal como ele estabelece em Os filhos do barro e em outros ensaios, embora tenha relação colateral com o surrealismo, do qual ele foi inclusive um partícipe, transcende o escopo do movimento surrealista. Na verdade a analogia é, para Paz, uma das matrizes de toda a modernidade, paralelamente a outra matriz, a ironia, representada por Laforgue, Corbière e outros poetas. Aliás, acredito que o pensamento analógico seja um dos procedimentos formais nucleares de toda a grande poesia, desde a Antiguidade, e que a literatura moderna o tenha apenas radicalizado. Basta lermos Píndaro, Lucano, Ovídio, as kenningar islandesas, a poesia medieval arábico-andaluza, Tasso e Ariosto, toda a poesia renascentista e o maior de todos os mestres da analogia e da agudeza: Góngora. Se formos mais longe, podemos entender o pensamento mágico-analógico como sendo de raiz platônicohermética. O próprio Paz realiza exatamente essa leitura em sua brilhante análise do ainda mais brilhante poema Sueño de Sóror Juana Inés de la Cruz, em seu monumental estudo crítico-biográfico Las trampas de la fe. Resumindo: acredito que haja sim no Brasil uma atenção ainda muito pequena a poetas mais espiritualistas e, por conseguinte, de matriz mítico-analógica. Isso ocorre por uma série de motivos e constrangimentos impossíveis de serem enumerados aqui. Para mim o motivo central está na ênfase sociológica e positivista da teoria da literatura no Brasil. Essa ênfase é compreensível se levarmos em conta diversos fatores políticos e ideológicos da história brasileira, mas hoje em dia já não o é mais, tendose em conta a grande abertura política ocorrida no país. Porém, mesmo considerando a minoridade crítica dessa tradição poética, penso que o melhor a fazer é a desvincularmos de movimentos organizados, como o surrealismo, ou mesmo de movimentos de cunho 
programático, como o neobarroco. E a pensarmos caso a caso, como sendo composta por um conjunto de autores que pertencem a uma tradição poética de muitos séculos. Desse modo é que se estabelece uma tradição, não por meio de adoção ou rejeição de manifestos. Pois toda tradição pode ser depreendida mediante uma análise formal das obras, sem necessidade de ser vinculada a movimentos e credos preexistentes.

14. Enfim, o ritmo em seus poemas, em consonância com a construção imagética, é extremamente encantatório, mágico, também analógico (diria Octavio Paz). Você concorda com a afirmação? A que se deve tal exploração requintada do ritmo?

Concordo totalmente com a análise de vocês sobre a base analógica dos meus poemas. Ela se deve a leituras e predileções que vão desde poetas a tratados alquímicos e ao meu gosto pela filosofia. Também se deve ao interesse específico que tenho pelo simbolismo e pela linguagem arquetípica. E, por fim, esse gosto pela analogia deve vir do fato de eu ser, no fundo, um platônico incurável.

15. Para concluirmos, você teceria alguns comentários sobre a relação da Universidade, hoje, com a poesia que se faz no Brasil?

Independentemente dos problemas, acredito que a universidade seja um dos melhores lugares para os escritores. É um espaço que deve ser colonizado por eles. Sobretudo por aqueles que, como eu, tenham uma inclinação natural para a teoria e o estudo. Com relação ao estudo de poesia contemporânea, não saberia afirmar nada. A impressão é a de que tem havido um espaço cada vez maior nas universidades para o estudo da literatura contemporânea, e isso é positivo. Porém, seria preciso dar um salto fundamental: criar uma verdadeira dinâmica de cadeiras, disciplinas e departamentos ministrados e coordenados por escritores. E com uma política de escritores-leitores convidados, como ocorre nos EUA e em países da Europa. Muitas vezes o escritor tem vontade de lecionar e compartilhar o seu conhecimento de literatura e os modos pelos quais ele construiu suas obras, mas se vê desanimado ao ter de enfrentar uma artilharia teórica pesada e muitas vezes desvinculada de sua escrita para chegar ao mestrado, ao doutorado e, por fim, à docência. Assim, cria-se uma situação um tanto absurda: as universidades produzem teses e teses sobre a obra de um escritor, mas este mesmo escritor não tem nenhuma voz ativa nas universidades. 